\title{
The Portability of American Job Involvement and Job Satisfaction Scales to Non-English Speaking South Africans
}

\section{Kamfer and D Venter}

University of Port Elizabeth

\author{
A B Boshoff \\ University of Pretoria
}

\section{ABSTRACT}

The scales discussed in Boshoff and Hoole (above) were applied to a sample of non-English mother tongue speakers in South Africa to test their "portability" between America and South Africa. Where more than one possible structure was obtained, they were compared by means of confirmatory factor analysis. To reduce error variance and improve goodness of fit indices, items were aggregated by taking the mean of random item clusters, and the confirmatory factor analyses repeated. The best fit solution for each of the scales was identified and discussed. Indications are that both the Minnesota Satisfaction Questionnaire and the Kanungo Job Involvement Scale can be used with confidence in South Africa, even on respondents who are not home language English speakers.

\section{INTRODUCTION}

It is not uncommon for a researcher to use a scale developed in one country to gather data in another, on the assumption that the scale would be measuring the same construct in its new area of application. Edwards \& Leger (1995) list various studies in which this has been done by researchers in Africa. The term "portability" has been applied to this aspect of construct validity, and was introduced into the South African literature by Boshoff, Julyan and Botes 
(1996) in their study of the Kanungo Job Involvement Questionnaire and the Minnesota Satisfaction Questionnaire (MSQ) from this perspective.

However, concerns have been expressed as to whether instruments developed in one cultural setting would be appropriate when used in another (Anastasi, 1982; Berry, Poortinga, Segall \& Dasen, 1992; Bhagat \& McQuaid, 1982; Bhagat, Kedia, Crawford \& Kaplan, 1990; Retief, 1988; Taylor, 1987; Triandis, 1972). Retief (1988) suggests a three-part framework (comparability and equivalence, translation of meaning, and bias) to describe the pitfalls that exist when applying tests across cultures. In an attempt to address these concerns, the International Test Commission (1994) has developed guidelines to be followed when using psychological instruments in cross-cultural studies.

At least two studies performed in this country, albeit involving different scales, have shown that different psychometric patterns sometimes occur when scales developed for one language group are applied to another (Edwards \& Riordan, 1994; Edwards \& Leger, 1995).

A major problem in the cross-cultural use of psychometric instruments appears to lie in the systems used to attribute meaning to events in different cultures (Poortinga, 1983; Retief, 1992).

Berry \& Triandis (1980) and Berry \& Lonner (1986) state that for scale scores obtained from different cultures to be comparable, the instrument used must show three types of equivalence: functional, ie the behaviour referred to should have a similar function in each culture; conceptual, an item should have the same meaning to members of both cultures, and metric, the scale used should have the same psychometric properties in both the cultural groups concerned.

This paper investigates the metric equivalence of the two scales being studied.

In a study which also focuses on the metric equivalence of these same two scales, Boshoff et al. (1996) used exploratory and confirmatory factor analyses to examine the structures produced for the scales on a South African sample which consisted of white collar professionals. They found the nine items which they retained from the Kanungo scale to measure one confirmed factor which accounted for $44.1 \%$ of the variance. The scale had an Alpha of .83. They also found the MSQ to be essentially unidimensional. One factor explained $36.3 \%$ of the variance and the scale alpha was .90. They concluded that both scales were robust as far as portability between the United States and South Africa is concerned. 
In this study, the portability of these two instruments was again examined, on a South African sample that differed in an important way from that used in the study of Boshoff and his colleagues: scales were applied to respondents who did not have English as their mother tongue

\section{METHOD}

\section{Instruments}

The instruments used in this study were again the two scales used in the previous study, ie the MSQ and Kanungo's Job Involvement scale.

\section{$M S Q$}

Median reliabilities of 90 have been reported for the short, 20 item form of the Minnesota Satisfaction Questionnaire (Weiss, Dawis, England and Lofquist, 1967). The MSQ measures job satisfaction in two dimensions, extrinsic and intrinsic, with 10 items for each dimension. A total satisfaction score is also provided by the responses to all 20 items. All items are positively worded.

\section{Kanungo's Job Involvement Scale}

The Kanungo (1982) job involvement scale contains 10 items and has developed as an improvement on the previously widely used measure of Lodahl and Kejner (1965), measuring job involvement as a unidimensional construct (Boshoff, Bennett \& Kellerman, 1994). Kanungo reported an Alpha coefficient of .83 for the scale. Two items are negatively phrased and have to be reverse scored.

\section{Sample}

The sample for this study was obtained from a South African government organization, the Department of Correctional Services. The sample frame was 540 employees to whom English was a second language. The two scales used were combined into one questionnaire which was applied by the human resources staff of the client organization. Completed questionnaires were received from 237 respondents $(43.9 \%)$. Non-response was mainly the result of unavailability of respondents on the day that the data gathering had been scheduled. 
Four of the respondents were Indian, 97 coloured, and 136 black. All were matriculated (had twelve years of schooling). Males numbered 213 (90\%) while $24(10 \%)$ were female. Mean length of service for the sample was 10.01 years, $S D=7.29$. Mean age for the Indian respondents was 32.5 years, $S D=10.5$; for the coloured respondents, $37.0, S D=10.3$ and for the black respondents 31.5 years, $S D=10.3$. The men had an average age of 30.5, $\mathrm{SD}=11.1$ and the women 33.5, $\mathrm{SD}=12.3$. Average age for the sample frame was 33 years, $S D=13.7$, and age range was 20 to 59 years.

\section{Analyses performed}

Program 4M of the BMDP (1990) statistical package was used to factor analyze the data. The extraction method was principal component factor analysis with direct quartamin oblique factor rotation to allow for intercorrelation between factors. Factor loadings greater or equal to .30 were regarded as significant. Both Kaiser's rule, ie factors with eigenvalues greater than one, and scree tests were used to aid in decisions on the optimal number of factors to retain. Items with maximum factor loadings less than .30 were omitted as well as items that loaded significantly on more than one factor. ltems were inverted where necessary to ensure that all were scored in the same direction. Cronbach's alpha was used to determine internal consistency. Confirmatory factor analysis, using the EQS computer package (Bentler, 1996) was performed for one-, two- and three-factor solutions for both scales, first for models consisting of the original items, and thereafter for models with aggregated scores. The following fit indices were inspected to determine which model provided the best fit: 
(a) Independence Model Chi-square;

(b) Model Chi-square;

(c) Akaike's Information Criterion (AIC);

(d) Bozdogan's Consistent Version of the AIC (CAIC);

(e) Bentler-Bonnet Normed Fit Index (BNFI);

(f) Bentler-Bonnet Nonnormed Fit Index (BNNFI);

(g) Comparative Fit Index (CFI);

(h) Residual Normed Index (RN);

(i) Robust Comparative Fit Index (RCFI);

(j) Bollen Fit Index (IFD;

(k) McDonald Fit Index (MFI);

(l) Lisrel Fit Index (GFI);

(m) Lisrel Fit Index (AGFD;

(n) Root Mean Square Residual (RMR);

(o) Root Mean Square Error of Approximation (RMSEA);

According to Bentler (1996), Chi-square values are inversely related to model fit. The RMR and RMSEA are also inversely related to model fit. The model that produces the minimum AIC or CAIC may be considered, in the absence of other substantive criteria, to be a potentially useful model. Regarding the fit indices, values greater than .90 are desirable.

\section{RESULTS}

\section{$M S Q$}

The indices obtained from the various confirmatory factor analyses conducted on the outcomes of the exploratory factor analyses for the MSQ are shown in Table 1. 
Table I Indices obtained from confirmatory factor analyses on MSQ

\begin{tabular}{|c|c|c|c|c|c|c|c|c|}
\hline & $\begin{array}{l}\text { Model } \\
\text { Chi- } \\
\text { Square }\end{array}$ & $\begin{array}{l}\text { Indepen- } \\
\text { dence } \\
\text { Model } \\
\text { Chi-Square }\end{array}$ & $\begin{array}{l}\text { Akaike's } \\
\text { Information } \\
\text { Criterion } \\
\text { (AIC) }\end{array}$ & $\begin{array}{l}\text { Bozdogan's } \\
\text { Consistent Ve } \\
\text { rsion of The } \\
\text { AIC } \\
\text { (CAIC) }\end{array}$ & $\begin{array}{l}\text { Bentler- } \\
\text { Bonnett } \\
\text { Normed } \\
\text { Fit Index } \\
\text { (BNFI) }\end{array}$ & $\begin{array}{l}\text { Bentler- } \\
\text { Bonnett } \\
\text { Nonnormed } \\
\text { Fit Index } \\
\text { (BNNFI) }\end{array}$ & $\begin{array}{l}\text { Compa- } \\
\text { rative } \\
\text { Fit } \\
\text { Index } \\
\text { (CFI) }\end{array}$ & $\begin{array}{c}\text { Residual } \\
\text { Normed } \\
\text { Index } \\
\text { (RNI) }\end{array}$ \\
\hline $\begin{array}{l}\text { Three- } \\
\text { factor } \\
\text { solution }\end{array}$ & 203.58 & $\begin{array}{c}850.97 \\
d / f=78\end{array}$ & 75.58 & -209.01 & .76 & .78 & .82 & .82 \\
\hline $\begin{array}{l}\text { Two- } \\
\text { factor } \\
\text { solution }\end{array}$ & $\begin{array}{c}410.90 \\
d / f=169 \\
\mathrm{e}<.00\end{array}$ & $\begin{array}{c}1574.11 \\
d / f=190\end{array}$ & 72.90 & -678.60 & .74 & .80 & .83 & .82 \\
\hline $\begin{array}{l}\text { One- } \\
\text { factor } \\
\text { solution }\end{array}$ & $\begin{array}{c}503.73 \\
d / f=170 \\
\mathrm{e}<.00\end{array}$ & $\begin{array}{c}1574.11 \\
d / f=190\end{array}$ & 163.73 & -592.22 & .68 & .73 & .76 & .76 \\
\hline
\end{tabular}


Table 1 (continued)

\begin{tabular}{|l|c|c|c|c|c|c|c|}
\hline & Robust & Bollen & Mc Donald & Lisrel & Lisrel ( & $\begin{array}{c}\text { Root mean } \\
\text { square } \\
\text { residual }\end{array}$ & $\begin{array}{c}\text { Root mean } \\
\text { square } \\
\text { error of } \\
\text { approxi- } \\
\text { ation } \\
\text { (RMSEA) }\end{array}$ \\
\hline $\begin{array}{l}\text { Three- } \\
\text { factor } \\
\text { solution }\end{array}$ & .83 & .82 & .74 & .89 & AGFI) & .85 & .21 \\
\hline $\begin{array}{l}\text { Two- } \\
\text { factor } \\
\text { solution }\end{array}$ & .85 & .83 & .59 & .85 & .81 & .09 & .08 \\
\hline $\begin{array}{l}\text { One- } \\
\text { factor } \\
\text { solution }\end{array}$ & .78 & .76 & .49 & .81 & .76 & .10 & .09 \\
\hline
\end{tabular}




\section{$M S Q$}

From Table 1 it can be seen that the three-factor solution is best on four of the indices reported, BNFI, MFI, GFI and AGFI. The two-factor solution has the best score on eight indices, AIC, CAIC, CFI, BNNFI, RCFI, IFI, RMR and RMSEA. The one-factor has no bests. The two-factor solution is shown in Table 2. In Table 2 (and later in Table 6) the factor loading matrix has been rearranged so that the columns appear in decreasing order of variance explained by factors. The rows have been rearranged so that for each successive factor, loadings greater than .30 appear first. For ease of reading, loadings less than .30 have been omitted.

The two-factor solution is preferred because it performs best on more of the goodness of fit indices produced by the confirmatory factor analysis than either of the other two solutions, although the three-factor solution also does well. Also in favour of the two-factor solution is the fact that it retains all of the original 20 items (compared with the 11 retained in the three-factor solution). It also has higher Cronbach's Alphas, .87 and .75 compared to the $.79, .66$ and .80 of the three-factor solution. Its configuration also closely resembles the ExtrinsicIntrinsic aspect of the MSQ in its original form. The two factors explain $40.62 \%$ of the total variance. Factor 1 contains 11 items, being all eight of the original "extrinsic" items, plus three "intrinsic" items. This factor explains $31.51 \%$ of total and $77.57 \%$ of common variance. Factor 2 contains 9 items, all "intrinsic". It explains $9.11 \%$ of total and $22.43 \%$ of common variance. The two factors correlate .41 with each other.

In their analysis of the MSQ, Boshoff et al. (1996) also retained all 20 items. They preferred a one-factor solution which had an alpha of .90, the one factor explaining $36.3 \%$ of total variance. Their confirmatory factor analysis fit indices were acceptable and better than the ones portrayed in Table 1, which are not very good.

In an attempt to improve the fit indices by reducing the error variance (Bagozzi \& Heatherton, 1994), the items in the MSQ were aggregated into subscales. This was done by taking the mean of random item clusters. The three-factor structure was represented by the following MSQ items (factors in square brackets and clusters in parantheses) $[(15,19,18),(16,20)] ;[(9,7,3)$, $(4,2,8)] ;,[6,5]$; two-factor structure was $[(19,6,5,16),(14,13,12,17),(15$, $18,20)]:[(10,1,9),(7,3,2),(8,11,4)]$. The one-factor structure contained all 20 items clustered as follows: $[(13,3,7,10),(8,15,4,5),(2,1,14,19),(12,6$, $17,9),(16,11,20,18)]$. 


\begin{tabular}{|c|c|c|c|c|}
\hline \multicolumn{3}{|c|}{ Table 2} & \multirow{3}{*}{\begin{tabular}{|l} 
solut \\
$\begin{array}{l}\text { Fac- } \\
\text { tor } 1\end{array}$ \\
.77 \\
\end{tabular}} & \multirow{3}{*}{$\begin{array}{l}\text { Fac- } \\
\text { tor } 2\end{array}$} \\
\hline \multicolumn{3}{|c|}{ MSQ Item } & & \\
\hline 17 & The working conditions & (E) & & \\
\hline 19 & The praise I get for doing a good job & (E) & .72 & \\
\hline 13 & My pay and the amount of work I do & (E) & .71 & \\
\hline 18 & The way my co-workers get along with each other & (E) & .67 & \\
\hline 12 & The way company policies are put into practice & (E) & .63 & \\
\hline 6 & The competence of my supervisor in making decisions & (E) & .63 & \\
\hline 16 & The chance to try my own methods of doing the job & (n) & .61 & \\
\hline 15 & The freedom to use my own judgement & (I) & .59 & \\
\hline 5 & The way my boss handles his workers & (E) & .58 & \\
\hline 14 & The chances for advancement on this job & (E) & .50 & \\
\hline 20 & The feeling of accomplishment I get from the job & (I) & .42 & \\
\hline 9 & The chance to do things for other people & (I) & & .78 \\
\hline 4 & The chance to be "somebody" in the community & (I) & & .61 \\
\hline 8 & The way my job provides for steady employment & (I) & & .60 \\
\hline 3 & The chance to do different things from time to time & (I) & & .58 \\
\hline 10 & The chance to tell people what to do & (n) & & .57 \\
\hline 11 & The chance to do something that makes use of my abilities & (I) & & .54 \\
\hline 2 & The chance to work alone on the job & (I) & & .42 \\
\hline 7 & Being able to do things that don't go against my conscience & (I) & & .41 \\
\hline 1 & Being able to keep busy all the time & (I) & & .37 \\
\hline & \% Common variance & & 77.57 & 22.43 \\
\hline & \% Total variance & & 31.51 & 9.11 \\
\hline & \% Total variance explained & & & 40.62 \\
\hline
\end{tabular}

E : Item measures extrinsic job satisfaction

I : Item measures intrinsic job satisfaction 
Confirmatory factor analyses were then performed to compare the degrees of fit produced for these aggregated structures. Results appear in Table 3.

Table 3 shows that the three-factor solution can be discarded as it performs significantly worse than the one- and two-factor solutions. Its model chi-square is significant. All its fit indices are unacceptably low, well below those of the other solutions.

The two-factor solution appears to be better than the one-factor solution: it does better on the model chi-square, AIC and CAIC whilst all the other fit indices are identical to those for the one-factor solution. For both two- and one-factor solutions model chi-square probabilities are not significant, which indicates a non-significant deviation from the postulated factor model.

In the two-factor solution, the two factors explain $71.58 \%$ of total variance, Factor 1 explaining $55.72 \%$ and Factor $2,15.86 \%$. Factor 1 explains $77.84 \%$ of common variance, and Factor $222.16 \%$. The factors correlate .55. Cronbach's Alpha for Factor 1 is .86, and for Factor 2, .73.

To summarize: the two-factor solution for the MSQ is preferred in both the non-aggregated and the aggregated analyses. In the non-aggregated analysis, the two factors explain $40.62 \%$ of total variance. Factor 1 accounts for $31.51 \%$ of total and $77.57 \%$ of common variance. Factor 2 explains $9.11 \%$ of total and $22.43 \%$ of common variance. The Cronbach's Alphas are .87 for Factor 1 and .75 for Factor 2 . The correlation between the factors is .41 . In the aggregated analysis, the two factors explain $71.58 \%$ of total variance, Factor 1 accounting for $55.72 \%$ and Factor 2 for $15.86 \%$. Factor 1 explains $77.84 \%$ and Factor 2, $22.16 \%$ of common variance. The factors correlate .55 . Cronbach's Alphas are .86 for Factor 1 and .73 for Factor 2 . 
Table 3 Indices obtained from confirmatory factor analyses on aggregated scales of MSQ

\begin{tabular}{|c|c|c|c|c|c|c|c|c|}
\hline & $\begin{array}{l}\text { Model } \\
\text { Chi- } \\
\text { Square }\end{array}$ & $\begin{array}{l}\text { Indepen- } \\
\text { dence } \\
\text { Model } \\
\text { Chi- } \\
\text { Square }\end{array}$ & $\begin{array}{c}\text { Akaike's } \\
\text { Information } \\
\text { Criterion } \\
\text { (AIC) }\end{array}$ & $\begin{array}{l}\text { Bozdogan's } \\
\text { ConsistentVe } \\
\text { rion of The } \\
\text { AIC } \\
\text { (CAIC) }\end{array}$ & $\begin{array}{l}\text { Bentler- } \\
\text { Bonnett } \\
\text { Nonned } \\
\text { Fit Index } \\
\text { (BNFI) }\end{array}$ & $\begin{array}{l}\text { Bentler- } \\
\text { Bonnett } \\
\text { Nonnormed } \\
\text { Fit Index } \\
\text { (DNNFI) }\end{array}$ & $\begin{array}{l}\text { Compa- } \\
\text { rative } \\
\text { Fit } \\
\text { Index } \\
\text { (CFI) }\end{array}$ & $\begin{array}{c}\text { Residual } \\
\text { Normed } \\
\text { Index } \\
\text { (RNI) }\end{array}$ \\
\hline $\begin{array}{l}\text { Three-factor } \\
\text { solution }\end{array}$ & $\begin{array}{c}84.40 \\
d / f=8 \\
p<.00\end{array}$ & $\begin{array}{c}525.55 \\
d / f=15\end{array}$ & 68.40 & 32.82 & .84 & .72 & .85 & .85 \\
\hline $\begin{array}{l}\text { Two-factor } \\
\text { solution }\end{array}$ & $\begin{array}{c}5.96 \\
d / f=8 \\
p=.65\end{array}$ & $\begin{array}{c}559.95 \\
d / f=15\end{array}$ & -10.04 & -45.62 & .99 & 1.00 & 1.00 & 1.00 \\
\hline $\begin{array}{l}\text { One-factor } \\
\text { solution }\end{array}$ & $\begin{array}{c}4.36 \\
d / f=5 \\
p=.50\end{array}$ & $\begin{array}{c}624.15 \\
d / f=10\end{array}$ & -5.64 & -27.87 & .99 & 1.00 & 1.00 & 1.00 \\
\hline
\end{tabular}


Table 3 (continued)

\begin{tabular}{|c|c|c|c|c|c|c|c|}
\hline & $\begin{array}{l}\text { Robust } \\
\text { (RCFI) }\end{array}$ & $\begin{array}{l}\text { Bollen } \\
\text { (IFI) }\end{array}$ & $\begin{array}{c}\text { Mc Donald } \\
\text { (MFI) }\end{array}$ & $\begin{array}{l}\text { Lisrel } \\
\text { (GFI) }\end{array}$ & $\begin{array}{l}\text { Lisrel ( } \\
\text { AGFI) }\end{array}$ & $\begin{array}{l}\text { Root mean } \\
\text { square } \\
\text { residual } \\
\text { (RMR) }\end{array}$ & $\begin{array}{l}\text { Root mean } \\
\text { square } \\
\text { crror of } \\
\text { approxi- } \\
\text { ation } \\
\text { (RMSEA) }\end{array}$ \\
\hline $\begin{array}{l}\text { Three-factor } \\
\text { solution }\end{array}$ & .87 & .85 & .85 & .91 & .75 & .25 & .20 \\
\hline $\begin{array}{l}\text { Two-factor } \\
\text { solution }\end{array}$ & 1.00 & 1.00 & 1.00 & .99 & .98 & .01 & .00 \\
\hline $\begin{array}{l}\text { One-factor } \\
\text { solution }\end{array}$ & 1.00 & 1.00 & 1.00 & .99 & .98 & .01 & .00 \\
\hline
\end{tabular}




\section{Kanungo's Job Involvement Scale}

Exploratory factor analyses were performed on Kanungo's Job lnvolvement scale producing three-, two- and one-factor solutions. Confirmatory factor analysis was conducted to determine the goodness of fit of the three solutions. Results appear in Table 4. 
Table 4 Indices obtained from confirmatory factor analyses on Kanungo

\begin{tabular}{|c|c|c|c|c|c|c|c|c|}
\hline . & $\begin{array}{c}\text { Model } \\
\text { Chi- } \\
\text { Square }\end{array}$ & $\begin{array}{l}\text { Indepen- } \\
\text { dence } \\
\text { Model } \\
\text { Chi- } \\
\text { Square }\end{array}$ & $\begin{array}{c}\text { Akaike's } \\
\text { Informatio } \\
\text { nCriterion } \\
\text { (AIC) }\end{array}$ & $\begin{array}{l}\text { Bozdogan's } \\
\text { ConsistentV } \\
\text { ersion of } \\
\text { The AIC } \\
\text { (CAIC) }\end{array}$ & $\begin{array}{l}\text { Bentler- } \\
\text { Bonnett } \\
\text { Normed } \\
\text { Fit Index } \\
\text { (BNFI) }\end{array}$ & $\begin{array}{l}\text { Bentler- } \\
\text { Bonnett } \\
\text { Nonnorme } \\
\text { d Fit } \\
\text { Index } \\
\text { (BNNFI) }\end{array}$ & $\begin{array}{l}\text { Compa- } \\
\text { rative } \\
\text { Fit } \\
\text { Index } \\
\text { (CFI) }\end{array}$ & $\begin{array}{c}\text { Residual } \\
\text { Normed } \\
\text { Index } \\
\text { (RND) }\end{array}$ \\
\hline $\begin{array}{l}\text { Three- } \\
\text { factor } \\
\text { solution }\end{array}$ & $\begin{array}{l}35.76 \\
d / f=8 \\
p<00\end{array}$ & $\begin{array}{c}316.83 \\
d / f=15\end{array}$ & 19.76 & -15.81 & .89 & .83 & .91 & .91 \\
\hline $\begin{array}{l}\text { Two- } \\
\text { factor } \\
\text { solution }\end{array}$ & $\begin{array}{c}69.48 \\
d / f=26 \\
p<00\end{array}$ & $\begin{array}{c}619.66 \\
d / f=36\end{array}$ & 17.48 & -98.14 & .89 &, 90 & .93 & .92 \\
\hline $\begin{array}{c}\text { One- } \\
\text { factor } \\
\text { solution }\end{array}$ & $\begin{array}{c}63.89 \\
d / f=20 \\
p<00\end{array}$ & $\begin{array}{c}616.79 \\
d / f=28\end{array}$ & 23.89 & -65.05 & .90 & .90 & .93 & .92 \\
\hline
\end{tabular}


Table 4 (continued)

\begin{tabular}{|c|c|c|c|c|c|c|c|}
\hline & Robust & Bollen & Mc Donald & Lisrel & Lisrel ( & $\begin{array}{c}\text { Root mean } \\
\text { square } \\
\text { residual } \\
\text { (RCFI) }\end{array}$ & $\begin{array}{c}\text { Root mean } \\
\text { square error } \\
\text { of approxi- } \\
\text { ation } \\
\text { (IFMSEA) }\end{array}$ \\
\hline $\begin{array}{c}\text { Three- } \\
\text { factor } \\
\text { solution }\end{array}$ & .94 & .91 & .94 & .95 & .88 & .15 & .12 \\
\hline $\begin{array}{c}\text { Two- } \\
\text { factor } \\
\text { solution }\end{array}$ & .95 & .93 & .91 & .93 & .88 & .07 & .09 \\
\hline $\begin{array}{c}\text { One- } \\
\text { factor } \\
\text { solution }\end{array}$ & .95 & .93 & .91 & .93 & .87 & .06 & .10 \\
\hline
\end{tabular}




\section{Indices obtained from confirmatory factor analyses on Kanungo}

Table 4 shows that the three-factor solution has the best score on two of the indices produced by the confirmatory factor analysis (MFI and GFI). The twofactor solution has three bests, AIC, CAIC, and RMSEA. The one-factor solution has two bests (BNFI and RMR). Compared with the two-factor solution, it does better on two indices, poorer on four, and equal on seven.

Its Alpha of .86 is better than those of the two-factor scale which are .84 and .59. It explains $47.95 \%$ of variance.

Model chi-squares are all significant, which indicate poor model fit. In order to improve the model fit and to reduce the error variance, the scales were aggregated randomly and confirmatory factor analyses performed for the twoand one-factor solutions. The three-factor solution could not be aggregated due to too few items per factor.

The two-factor configuration consisted of the following clusters: $[(8,5$, $9,6),(4,1,10)] ;[7,2]$, and the one factor configuration $[(5,9)(3,6)(10,8)$ $(4,1)]$.

Results appear in Table 5. 
Table 5 Indices obtained from confirmatory factor analyses on aggregated scales of Kanungo

\begin{tabular}{|c|c|c|c|c|c|c|c|c|}
\hline & $\begin{array}{c}\text { Model } \\
\text { Chi- } \\
\text { Square }\end{array}$ & $\begin{array}{l}\text { Indepen- } \\
\text { dence } \\
\text { Model } \\
\text { Chi- } \\
\text { Square }\end{array}$ & $\begin{array}{c}\text { Akaike's } \\
\text { Informatio } \\
\text { nCriterion } \\
\text { (AIC) }\end{array}$ & $\begin{array}{l}\text { Bozdogan's } \\
\text { ConsistentV } \\
\text { ersion of } \\
\text { The AIC } \\
\text { (CAIC) }\end{array}$ & $\begin{array}{l}\text { Bentler- } \\
\text { Bonnett } \\
\text { Nornied } \\
\text { Fit Index } \\
\text { (BNFI) }\end{array}$ & $\begin{array}{l}\text { Bentler- } \\
\text { Bonnett } \\
\text { Nonnorine } \\
\text { d Fit } \\
\text { Index } \\
\text { (BNNFI) }\end{array}$ & $\begin{array}{l}\text { Conipa- } \\
\text { rative } \\
\text { Fit } \\
\text { Index } \\
\text { (CFI) }\end{array}$ & $\begin{array}{c}\text { Residual } \\
\text { Norned } \\
\text { Index } \\
\text { (RNI) }\end{array}$ \\
\hline $\begin{array}{l}\text { Three- } \\
\text { factor } \\
\text { solution }\end{array}$ & $\begin{array}{l}35.76 \\
d / f=8 \\
p<00\end{array}$ & $\begin{array}{c}19.76 \\
d / f=15\end{array}$ & 19.76 & -15.81 & .89 & .83 & .91 & .91 \\
\hline $\begin{array}{l}\text { Two- } \\
\text { factor } \\
\text { solution }\end{array}$ & $\begin{array}{c}69.48 \\
d / f=26 \\
p<00\end{array}$ & $\begin{array}{c}17.48 \\
d / f=36\end{array}$ & 17.48 & -98.14 & .89 & .90 & .93 & .92 \\
\hline $\begin{array}{c}\text { One- } \\
\text { factor } \\
\text { solution }\end{array}$ & $\begin{array}{c}63.89 \\
d / f=20 \\
p<00\end{array}$ & $\begin{array}{c}23.89 \\
d / f=28\end{array}$ & 23.89 & -65.05 & .90 & .90 & .93 & .92 \\
\hline
\end{tabular}


Table 5 (continued)

\begin{tabular}{|c|c|c|c|c|c|c|c|}
\hline & Robust & Bollen & Mc Donald & Lisrel & Lisrel ( & $\begin{array}{c}\text { Root mean } \\
\text { square } \\
\text { residual }\end{array}$ & $\begin{array}{c}\text { Root mean } \\
\text { square error } \\
\text { of approxi- } \\
\text { ation } \\
\text { (RMSEA) }\end{array}$ \\
\hline $\begin{array}{c}\text { Three- } \\
\text { factor } \\
\text { solution }\end{array}$ & .94 & .91 & .94 & .95 & .88 & .15 & .12 \\
\hline $\begin{array}{c}\text { Two- } \\
\text { factor } \\
\text { solution }\end{array}$ & .95 & .93 & .91 & .93 & .88 & .07 & .09 \\
\hline $\begin{array}{c}\text { One- } \\
\text { factor } \\
\text { solution }\end{array}$ & .95 & .93 & .91 & .93 & .87 & .06 & .10 \\
\hline
\end{tabular}


The one-factor solution for Kanungo produces the best results, having the highest scores on 12 of the confirmatory factor analysis indices. The one factor accounts for $70.01 \%$ of total variance, and has an Alpha of .86 compared to .87 and .59 for the two-factor, and $.80, .59$, and undefined for the three-factor solution.

The one-factor solution retains eight of the original 10 items, only losing both the negatively phrased ones. The one-factor solution is shown in Table 6

\begin{tabular}{|l|l|c|}
\hline \multicolumn{2}{|c|}{ Table 6} & \multicolumn{2}{c|}{$\begin{array}{c}\text { Sorted rotated factor loadings for best fit, one-factor solution } \\
\text { after exploratory factor analysis on Kanungo's JIQ }\end{array}$} \\
\hline \multicolumn{2}{|c|}{ Kango Item } & Factor 1 \\
\hline 5 & Most of my interests are centered around my job & .78 \\
\hline 4 & I live, eat and breathe my job & .76 \\
\hline 6 & $\begin{array}{l}\text { I have very strong ties with my present job which } \\
\text { could be very difficult to break }\end{array}$ & .73 \\
\hline 9 & I consider my job to be very central to my existence & .72 \\
\hline 10 & I like to be absorbed in my job most of the time & .72 \\
\hline 8 & Most of my personal life goals are job-orientated & .69 \\
\hline 3 & I am very much involved personally in my job & .56 \\
\hline 1 & The most important things that happen to me & .53 \\
\hline & involve my present job & 47.95 \\
\hline
\end{tabular}

In sum, in its non-aggregated form, the one-factor solution of the Kanungo scale retained eight items, explaining $47.95 \%$ of variance and having an Alpha of .84. When aggregated into scales, the aggregated one-factor solution accounts for $70.01 \%$ of variance with an Alpha of .86 .

The confirmatory factor analysis indices for the aggregated solution are all better than those for the non-aggregated solution. The non-significant model chi-square statistic is further indication of good model fit. 
In the Boshoff et al. (1996) study, one of the two negatively phrased items was dropped. The remaining nine items (one more than was retained in this analysis) formed a one-factor solution which had an alpha of .83 and explained $44.1 \%$ of total variance, which is slightly less than our result. Their confirmatory factor analysis (on non-aggregated scale) produced fit indices that were good, being in the mid to high nineties, which were even better than those found in this study for the non-aggregated scale.

\section{CONCLUSION}

The two scales tested on this sample both retained their structure to a large degree.

The MSQ retained all 20 of its items (in the context of the comment made in the second last paragraph below it is significant to note that all were positively worded originally) in a two-factor configuration that closely replicated the original extrinsic and intrinsic dimensions. Internal consistency was satisfactory. This solution differed from that obtained by Boshoff, el al. (1996), who preferred a one-factor solution. While the fit indices produced by the confirmatory factor analysis on the non-aggregated MSQ in this sample were not very good, those obtained from the analysis on aggregated items were high.

Kanungo's Job Involvement Scale retained eight of the original 10 items, losing only the two negatively phrased items. The single factor solution had good internal consistency. Boshoff et al. (1996) also found a one-factor solution, retaining nine items, again with good internal consistency.

Boshoff et al. (1996) commented on the possible effect of the nature of the foreign sample in the interpretation of (their) portability results. The sample in their study (white, middle and upper middle class professionals) did materially differ from the one used as raison d'etre for this study, who were all non-English mother tongue speakers with a high-school education. Despite this difference, the results obtained for the Kanungo Job Involvement scale were very similar to those of Boshoff et al. They retained one more item, and their fit indices were higher. The structure obtained for the MSQ in this study was different, and the fit indices were again lower - proving their point to some degree.

It is interesting that the two negatively phrased items in the Kanungo scale did not perform well in the item analysis and both were discarded. In the 
Boshoff et al. (1996) study, one negative item was discarded. This may not be strong evidence, but the comment by Schmitt and Stults (1985) (quoted by Tetrick \& Farkas, 1988) reporting a concern about the use of negatively worded items to reduce response tendency does spring to mind.

Despite the fact that the sample on which the MSQ and Kanungo's Job Involvement Scale were applied in this study differed from the one used by Boshoff et al. (1996), the conclusion can be made that both scales again performed at least reasonably well and could be considered for further use on non-English speaking groups in South Africa. The MSQ held up very well and could be used with confidence virtually as is. The eight positively worded items of Kanungo's scale would provide a good scale for measuring job involvement.

This study concentrated mainly on the aspect of metric equivalence (Berry \& Triandis, 1980; Berry \& Lonner, 1986). Poortinga (1983) warns that psychometric analysis is in itself a limited way of investigating equivalence. Bhagat \& McQuaid (1982) have questioned whether job satisfaction, the focal area of one of the scales examined in this paper, would hold the same connotation for workers in other countries that it holds in the United States. These aspects have not been adequately dealt with in this paper. The fact that the two scales stood up well psychometrically may in itself suggest that there were no great conceptual differences involved. However, the fact that the patterns obtained did differ to a degree, and that, where used, the reverse scored items had to be discarded does indicate that there may be some differences. Therefore, whether these two scales also have functional and conceprual equivalence still has to be shown.

\section{NOTE}

The financial assistance of the Centre for Science Development, Human Sciences Research Council, which enabled the first-mentioned author to present a version of this paper at an overseas conference, is gratefully acknowledged. 


\section{REFERENCES}

1. ANASTASI, A. (1982). Psychological Testing. New York. Macmillan.

2. BAGOZZI, R.P., \& HEATHERTON, T.F. (1994). A general approach to representing multifaceted personality constructs: Application to state self-esteem. Structural Equation Modeling, 1(1), 35-67.

3. BENTLER, P.M. (1996). EQS structured equations program manual. Multivariate Software Inc., 4524 Balboa Boulevard \#368, Encino, California 91316.

4. BENTLER, P.M. (1996). Covariance structure analysis: Statistical practice, theory and directions. Annual Review of Psychology, 47, 563592.

5. BERRY, J.W., \& LONNER, W.J. (Eds.) (1986). Field methods in cross-cultural research. Beverley Hills, CA, Sage.

6. BERRY, J.W., \& TRIANDIS, H.C. (Eds.) (1980). Handbook of crosscultural psychology. Vol 2. Boston, Allyn \& Bacon.

7. BERRY, J.W., POORTINGA, Y.H., SEGALL, M.H., \& DASEN, P.R. (1992). Cross-cultural psychology: Research and applications. Cambridge, Cambridge University Press.

8. BHAGAT, R.S., \& MCQUAID, S.J. (1982). Role of subjective culture in organizations: $A$ review and directions for future research. Journal of Applied Psychology (Monograph), 67, 653-685.

9. BHAGAT, R.S., KEDIA, B.C., CRAWFORD, S.E., \& KAPLAN, M.R. (1990). Cross-cultural issues in Organizational Psychology: Emergent trends and directions for research in the 1990's. International Review of Industrial and Organizational Psychology, 5, 59-99.

10. BMDP Statistical Software Manual (1990). BMDP Statistical Software, Inc., 1440 Sepulveda Boulevard, Suite 316, Los Angeles, California, 90025.

11. BOSHOFF, A.B., BENNETT, H.F., \& KELLERMAN, A.M. (1994). Prediction of job involvement of pro-fessionals by means of career orientation scores. Journal of Industrial Psychology, 20(2), 8-13.

12. BOSHOFF, A.B., JULYAN, S., \& BOTES, J.C. (1996). Portability of the job involvement and job satisfaction constructs between the United States of America and South Africa. Journal of Industrial Psychology, in press. 
13. COOK, J.D., HEPWORTH, S.J., WALL, T.D., \& WARR, P.B. (1981). The experience of work: A compendiun and revue of 249 measures and their use. London, Academic Press.

14. EDWARDS, D., \& RIORDAN, S. (1994). Learned resourcefulness in black and white South African university students. Journal of Social Psychology, 134(5), 665-675.

15. EDWARDS, D., \& LEGER, P. (1995). Psychometric properties of the Right Wing Authoritarianism Scale in black and white South African students. International Journal of Psychology, 30(1), 47-68.

16. International Test Commission. (1994). Guidelines for adapting educational and psychological instruments and establishing score equivalence. Draft distributed at the Congress of the International Association of Applied Psychology. Madrid, July 17-22.

17. POORTINGA, Y.H. (1983). Psychometric approaches to intergroup comparison: The problem of equivalence. In S.H. Irvine \& J.W. Bern; $(E d s)$, Human assessment and cultural factors. New York, Plenum.

18. RETIEF, A. (1988). Method and theory in cross-cultural psychological assessment. Pretoria, Human Sciences Research Council.

19. SCHMITT, N., \& STULTS, D.M. (1985). Factors defined by negatively keyed items: The result of careless respondents? Applied Behavioural Measurement, 9, 367-373.

20. TAYLOR, T.R. (1987). Test bias: The roles and responsibilities of test user and test publisher. NIPR Special Report Pers-424. Pretoria: Human Sciences Research Council.

21. TETRICK, L. E., \& FARKAS, A. J. (1988). A longitudinal examination of the dimensionality and stability of the organizational commitment questionnaire (OCQ), Educational and Psychological Measurement, 48, 723-735.

22. TRIANDIS, H.C. (1972). The analysis of subjective culture. New York: Wiley. Weiss, D.J., Dawis, R.V., England, G.W., \& Lofquist, L.H. 1967. Manual for the Minnesota Satisfaction Questionnaire. Minnesota Studies in Social Rehabilitation, 22. Minneapolis, University of Minnesota. 